\title{
A ROLE FOR HR IN CORPORATE ETHICS? SOUTH AFRICAN PRACTITIONERS' PERSPECTIVES
}

\author{
LJ VAN VUUREN \\ ljvv@rau.ac.za \\ Programme in Industrial Psychology \\ Department of Human Resource Management \\ University of Johannesburg \\ RJ EISELEN \\ Statistical Consultation Services \\ University of Johannesburg
}

\begin{abstract}
Since few South African organisations have as yet appointed ethics officers, there is often a lack of clarity on who should take responsibility for coordinating organisations' ethics management efforts. The purpose of this paper was to assess HR (the Human Resource function and its practitioners) as a possible contender to assume responsibility for ethics management in SA organisations. To this end a mail survey was conducted among registered HR practitioners $(\mathrm{N}=410)$. Two factors related to 1) the extent of HR's ethics management competence and 2) HR's responsibility for ethics management, were identified. The results showed that HR practitioners on average believe that they indeed have an ethics management competence and that they should be involved in ethics management. However, practitioners with a great deal of exposure to organisations that manage ethics believe to a lesser extent that they should be involved in ethics management. The implications of the findings are discussed.
\end{abstract}

Key words

Ethics, human resources, ethics management

South African businesses are increasingly embarking on focused and structured attempts at managing ethics. Within the South African context, the recommendations of the King I Report on Corporate Governance published in 1994, and to an even greater extent, the recommendations of the King II Report, published in 2002 (IoD, 2002), clearly stipulate the institutionalisation and management of ethics as a primary focus of good governance. The King paradigm of corporate governance is built on the premise that governance is not only an ethical imperative, but also that ethics has to be governed and ethical performance reported on. Organisations are, however, still somewhat ill at ease not only with the 'how' of managing ethics, but also with the 'whom' that should assume responsibility for coordinating organisations' ethics management efforts.

Organisations in the United States of America have formalised the role of the ethics officer as "manager" of the organisation's ethics performance since the mid-1980's when companies started to create dedicated ethics management functions, or ethics offices, managed by "ethics officers" (EOA, 1999). Of late, several organisations in Europe have shifted their traditional focus of business ethics away from corporate social responsibility (CSR) issues to managing ethics performance within organisations. Most South African organisations that decide to manage ethics proactively and want to establish in-house structures to achieve this, seem to prefer a somewhat tentative approach until such time as the viability of a full-blown ethics management function becomes imperative. These organisations therefore allocate corporate ethics management responsibilities to existing corporate functions as over-and-above roles to be performed. Examples of such functions that can be given ethics management responsibilities are financial management, internal audit, compliance, corporate legal services, risk management, procurement, the company secretariat, or the human resource function (HR) and/or one or more of its affiliate functions (e.g. organisational development, employment relations or human resource development). It seems that organisations are uncertain as to exactly where to locate the quasi ethics management function that comes about when such an over-and-above approach is adopted.

As custodian of organisational values, HR indeed has an active role to play regarding the raising of the corporate ethical consciousness, the facilitation of ethical behaviour and the promotion of ethical leadership (British perspective provided by: Arkin, 1996; Johns, 1995; Pickard, 1995; Pocock, 1989; Wehrmeyer, 1996; US perspective provided by: Bartels, Harrick, Martell \& Strickland, 1998; Caudron, 1997; Compton, 1997; Driscoll \& Hoffman, 1998; Flynn, 1995; Greengard, 1997; Grensing-Pophal, 1998; Hosmer, 1987; Koys, 1988; Lawler, 1988; Losey, 1997; Raelin, 1987; Smith \& Carroll, 1984). What is unclear, however, is whether HR should assume responsibility for ethics management, and whether HR should coordinate corporate ethics management initiatives.

The aim of this article is to explore the option of HR assuming responsibility for corporate ethics management. It is therefore necessary to analyse supporting and opposing views to this option. Thereafter an empirically based survey of South African HR practitioners' perspectives on their perceived role in assuming responsibility for managing ethics will be reported and discussed.

\section{Arguments in favour of HR managing ethics}

Several scholars hold strong views on the role of HR in managing ethics. A survey $(\mathrm{N}=1078)$ by Danley, Harrick, Schaefer, Strickland and Sullivan (1996) among corporate US HR managers, showed that $50 \%$ of the respondents regarded "advocate of employees" as an important part of their role. The "employee advocate" role is aligned to what Ulrich (1997) labels an "employee champion" role (one of the four major generic HR roles as proposed by Ulrich). Other authors describe HR's role as "custodian" of organisational values (Armstrong, 1995; Torrington \& Hall, 1995; Sadler, 1995). Research by Foote and Robinson (1999) indicated that HR managers perceived themselves as guardians of organisational values. Foote (2001) claims that HR's role as the "conscience" of the organisation has a long pedigree. Lowe (in Foote, 2001) refers to the human resource management role as the organisation's "arbiter of justice and acolyte of benevolence" (p. 28), and Woodd (in Foote, 2001) is quite clear that such a role still remains. Does being an employee champion or advocate, or custodian or guardian of values, however, qualify HR to take the lead in managing corporate ethics?

According to Driscoll and Hoffman (1998) "HR as the ethics office isn't an oxymoron" and "Safeguarding the company is human resources' job. Increasingly, HR managers are taking the 
lead in recognizing the need for ethics programs and in making them happen" (p. 121). The reasons they provide are that those in leadership positions in human resources are highly respected within their organisations for integrity, having the ability to solve complex ethical dilemmas, understanding the company's culture and communicating it at all hierarchical levels in the organisation. Driscoll and Hoffman (1998) claim that even in smaller companies that do not have the resources for a separate ethics function", ethics initiatives properly fit as part of the human resources department" (p. 121). Wiley (1998) too, believes that HR has a role to play in taking responsibility for ethics management. She bases her opinion on research findings which revealed that it is appropriate for HR to assume a responsibility for corporate ethics.

Donaldson (in Digh, 1997) suggests that "70 per cent of the responsibility for values and ethics should fall to HR" (p.92). Woodd (in Foote, 2001) sees HR specialists as located ideally "... at the heart of policy design and implementation, involved in the training of employees, and responding to change through organisational development" (p. 28). A 1997 survey conducted by the Society for Human Resource Management in conjunction with the Ethics Resource Centre, indicated that " 70 per cent of HR professionals are involved in formulating ethics policies and 69 per cent are a primary resource for their enterprises' ethics initiative" (Brewster, Carey, Dowling, Grobler, Holland \& Wärnich, 2003).

Drummond (in Pickard, 1995) states that since ethics is about people's behaviour, HR departments ought to be interested in managing ethics. He further claims that HR concerns itself with people's standards and behaviour as well as performance - in ethics management, standards and behaviour are also crucial factors. Ethics also plays a part in performance management in that performance is affected by ethically related issues, e.g. "treating others with respect" would influence the interpersonal relationship dimension present in performance appraisal systems.

Kilcourse (1994) explains that value leadership is a key role for top management and that values rest on a philosophical foundation, knowingly or not. He further states that of all the people in top management, the human resource director has the largest responsibility to promote the company values and the philosophy. "By making explicit those values which drive the organisation" and "disseminating a list of clear ethical guidelines" (Kilcourse, 1994, p. 42), the HR director persuades other executives that the inculcation of a values system is crucial for leadership success.

Caudron (1997) is adamant that "HR professionals must be able to understand and enforce ethical business behaviour" (p. 63). Berenbeim (1991) notes that of all the major functional corporate departments, HR has the greatest familiarity and expertise with the major issues (e.g. work force diversity, participative management, the abandonment of the lifetime employeremployee relationship, etc.), that have contributed to equip employees with the resources to align business priorities with individual and group moral claims. He further points out that the majority of specific issues covered by corporate codes of ethics relate to some extent to employees' contracts with the company. He proposes this as the reason why the HR manager should have an intensive participation in the formulation, articulation, dissemination, implementation, assessment, and revision of company ethics policies, codes, guidelines, as well as ethics management programs. The intensification of the HR contribution to corporate ethics programs adds a degree of substantive involvement to HR responsibilities - a trend that promises to become more profound in future (Berenbeim, 1991).

Woodd (in Foote, 2001) argues that an underlying value for human resource specialists must be to act as the guardians of ethical conduct. Although she emphasises that ethics is the responsibility of senior management, she claims that without a proactive approach from those (HR) who are involved with the people side of the business, real (ethical) issues will never be raised.

The Danley, et al. (1996) survey revealed that besides dealing with the many delicate ethical issues within HR practice, $83 \%$ of HR managers see themselves as currently taking the most responsibility for ethical leadership and guidance in their organisations (followed by top management, legal counsel, immediate supervisors, etc.). The results also showed that the responsibility gap as perceived by HR regarding its role in discharging the responsibility for ethical guidance and leadership, is $12 \%$. This represents the percentage difference between those who are responsible and those who should be responsible for corporate ethical guidance.

With regard to training in ethics, $79 \%$ of ethics officers that responded to the 2001 Ethics Officer Association (EOA) survey, reported that the organisation's ethics office provides training and/or continuing education on ethical business conduct to employees (EOA, 2002) while $61 \%$ of ethics officers polled responded that their organisations' HR departments provide substantial training in ethics. Thirty eight per cent of ethics officers that responded to the survey, indicated that their organisations' HR departments determine the content of ethics training programs (EOA, 2002).

Brewster et al. (2003) refer to a survey by Carey in 2000 which indicated that Australian HR managers play a prominent role in ethics management. They are responsible for the formulation of written ethics standards, communicating these standards, as well as monitoring and enforcing compliance to the standards. Brewster et al. (2003) suggest that "HR is well-positioned to make an important contribution to creating, implementing and sustaining ethical organisational behaviour within a strategic HR paradigm" (p. 270).

According to the above opinions, it appears as if HR is capable of assuming responsibility for organisational ethics management initiatives. Several authors are, however, opposed to HR assuming this responsibility for reasons set out below.

Arguments not in favour of a role for HR in managing ethics Pickard (1995) claims that there is evidence that ethics is the latest big issue to pass over the heads of HR departments. Cavanagh (in Pickard, 1995) warns that the question of whether HR professionals want to be involved, needs to be posed. Her reservations in this regard are based on the possibility that HR professionals may view ethics as "just another soft subject that will dent their credibility with the hard men who run the company" (p. 25), and not necessarily as a key factor in performance and profitability.

Winstanley, Woodall and Heery (1996) note that the ethics stewardship role for HR is problematic. Should HR assume this role, line managers may argue that ethics is HR's responsibility, thus negating their own day-to-day role of managing the ethics of their work teams. A survey by Foote and Robinson (1999) among senior HR practitioners in the UK revealed that when ethical responsibility for the organisation is placed explicitly with the HR function, line managers are allowed the 'freedom' to absolve themselves of any ethical responsibility for their actions. Should ethics become an HR responsibility, an additional complication is that ethics may become "just another HR project ...". Should contributions be required from line in the design phase of ethics management systems, HR practitioners may experience the same type of resistance that usually characterises line management's responses to new HR systems (e.g. a new performance management system).

Connock and Johns (1995) argue that ethical leadership must come from top management and "not be part of the ghetto of human resource management". Recent moves to elevate HR's 
status to business partner has, among others, been a deliberate attempt to raise the status of the function by moving it away from its 'welfarist' roots, and to be more closely aligned with strategy and with board-level representation (Winstanley, et al., 1996). There is of course the risk that by assuming responsibility for ethics, the HR function may again jeopardize its status and credibility. Foote and Robinson (1999) found that 'managing ethics' was not identified as a competence by the HR practitioners that responded to their survey. Their survey also showed little evidence of HR professionals being able to exert much influence on organisational ethics. They claim that this inability to have an effect on the ethics of an organisation " is determined by the interaction between the organisation and the individual which is, in turn, dependent on the status, credibility and influence of the HR specialists themselves" (p. 89). Robertson and Schlegelmilch (1993) found that organisations in the UK tend to communicate ethics policies through senior management other than HR. Therefore: HR must do the work, but since they do not have sufficient credibility, other executives must continuously endorse ethics management initiatives.

HR practitioners find themselves somewhere between two extremes: having to assume an "independent, neutral, and impartial stance in balancing the demands of the bottom line and the interests of the employees" (Foote, 2001). A similar brand of tension is present when $\mathrm{HR}$ practitioners find themselves in the position where they are seen to be pro-union by management, and pro-management by unions. A further danger may be that HR may become lawmaker, enforcer, judge and advisor when given an ethics management role.

As mentioned earlier, research by Foote and Robinson (1999) revealed that 'managing ethics' was not identified as a competence by practitioners that responded to their survey. Should this be the case elsewhere - in South Africa for example - the question has to be raised as to whether HR practitioners indeed have the skills acquired through formal and informal training, to take responsibility for ethics management. It is beyond dispute that members of the formalised component of the HR profession in South Africa are serious about professional ethics. This is evident from current efforts of the profession to have their practitioners' professional status formally entrenched by legislation, and where this proposed legislation contains adequate provision for ensuring ethical conduct by members of the profession. There seems to be little indication, however, that the HR profession in South Africa is concerned with managing ethics as a competence for its practitioners. A scrutiny of documents and policies of standards generating bodies and professional boards and associations, revealed no formal evidence that ethics management is perceived as being an important competence HR practitioners need to possess and/or acquire. This seems to indicate that the HR profession in South Africa has not given much thought to the possibility of HR assuming responsibility for corporate ethics management.

Lastly, it can be questioned whether HR really has both the task- and energy-based capacities to assume responsibility for ethics. As such the high expectations on HR, not only to take on a business partner responsibility for improving the bottom line, but also to spend large amounts of emotional energy in being people champions, may put a further, perhaps unfair demand on HR practitioners to take on the complex and potentially time and energy consuming role of managing ethics, where the latter may be a responsibility over-and-above their usual tasks.

It is clear that there are many risks for HR when they attempt to be 'the conscience of the organisation'. Some of these risks relate to ethics being just another (albeit newer) soft, 'welfarist' issue to be presented for buy-in from line, doubts over HR's ability to actually influence organisational ethics, line management absolving themselves of their responsibility for ethics since it "is now HR's problem", the non-identification of ethics as a key HR competence (possibly due to inadequate training and/or skills in this regard), the possibility that taking care of ethics may dilute the newly established business partner role, and the phenomenon that a responsibility for ethics should not be added as an additional burden to an already saturated HR role. Most of these risks emanate from HR's credibility issue, which in turn, may cause a severe reluctance from HR to assume responsibility for ethics.

Several stakeholders' opinions could be sought to determine whether HR should 1. assume responsibility for ethics management in organisations, 2 . possess or acquire an ethics management competence, and therefore 3 . be educated and trained in ethics management principles and practices. As such one could survey other functions in organisations (e.g. governance, legal, compliance, finance, audit, the company secretariat and risk management functions). Senior executives and line managers would also provide indications of the possibility of HR taking on ethics as a responsibility. The professional bodies and associations that regulate, structure and coordinate HR practitioners' activities could also be polled. However, in light of the fact that it will eventually be the practitioners themselves that will have to fulfil the requirements of an ethics management role, the researchers deemed it appropriate to firstly ascertain what the perceptions of the HR practitioners themselves are in this regard. In the process one could get closer to establishing what the ideal dispensation could be for South African organisations and the HR practitioners operating within these organisations.

\section{RESEARCH DESIGN}

\section{Participants}

The population consisted of the 1969 HR practitioners registered at all levels of registration categories with the South African Board for Personnel Practice (SABPP). Questionnaires were mailed to the practitioners who were requested to complete and return the questionnaires to the researchers within a specified period of time.

\section{Measuring instrument}

The mail survey data collection method was utilised for the purpose of this study, which entailed distributing questionnaires to the population of registered HR professionals. Apart from background information, which included age, gender, educational qualification and experience in the HR field, the questionnaire elicited specific information regarding ethics. These included questions related to the adequacy of training in ethics during formal education. In additional, 21 opinion-related questions, each measured on a 3 -point ordinal scale (small extent/moderate extent/large extent), elicited information regarding the role of $H R$ in dealing with ethical issues. Finally, 12 yes/no questions elicited specific information about exposure to a context where ethics is managed within the organisation.

\section{Procedure}

As per the guidelines of Alreck and Settle (1995, pp. 183-209) concerning the survey research method, a covering letter accompanied the questionnaire. The covering letter explained the purpose and importance of the study and ensured the anonymity of respondents. The questionnaire was mailed to the selected population and included a pre-paid envelope. Participants were requested to complete the questionnaire and to return it by the date stipulated in the cover letter. In an attempt to increase the response rates, a follow-up email was sent to each member of the selected population as a reminder of the request to participate in the survey. 
Limitation of the study

Although the questionnaire was mailed to the entire population of HR practitioners registered at all levels of registration categories with the South African Board for Personnel Practice (SABPP), those who chose to respond do not necessarily constitute a random or representative sample of the population.

\section{RESULTS}

\section{Description of the background of the sample}

A total of $410(20,82 \%)$ practitioners provided complete information on the 21 items relating to the role of HR in dealing with ethical issues. The majority of these respondents (335 or $81,7 \%$ ) were male. The ages of respondents varied from 25 to 76 years with an average of 45,45 years $(S D=8,56)$ and they had between 4 and 40 years of experience in the HR field with a mean of 18,63 years $(S D=7,4)$. In particular, $16,1 \%$ had less than 10 years experience, $21,2 \%$ had between 10 and 15 years experience, $25,1 \%$ had between 16 and 20 years experience and $17,1 \%$ had 26 or more years of experience.

There were 309 (75.40\%) respondents who occupied permanent positions within their respective organisations, with only 70 $(17,10 \%)$ self-employed as consultants, while $5,1 \%$ indicated occupying both a permanent position within an organisation and being self-employed. The majority of the respondents were in senior HR manager positions $(33,20 \%)$, with $20,50 \%$ in director positions. Only $10,0 \%$ were junior HR managers, and $12,70 \%$ were at entry-level. This explains the fact that most of the respondents had more than 10 years experience. In terms of tertiary qualifications, 89 respondents $(21,70 \%)$ had bachelor's degrees, $92(22,40 \%)$ honours degrees, 99 (24,10\%) master's degrees while $32(7,80 \%)$ had doctoral degrees.

\section{Description of responses to questions on HR and} organisational ethics

As far as the adequacy of training in ethics/business ethics during formal education is concerned (see Figure 1), responses ranged between 1 (totally inadequate training in ethics) and 6 (totally adequate training in ethics) with a mean of $3,2(\mathrm{SD}=$ $1,17)$.

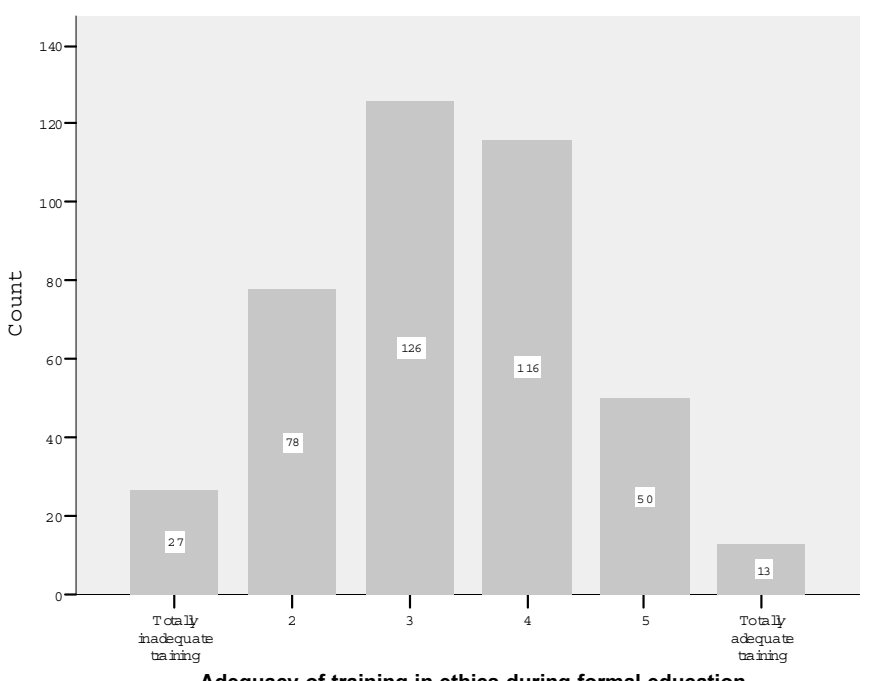

Figure 1: Responses to the adequacy of training in ethics during formal training

Responses to the opinion-related questions, i.e. the questions related to HR's role in the management of ethics, are summarised in Table 1 . These show that the majority of respondents believed that HR practitioners should be involved in business ethics and that business ethics should be included in the training of HR practitioners.
TABle 1

Percentage of Responses

\begin{tabular}{|c|c|c|c|}
\hline Extent to which... & $\begin{array}{l}\text { Small } \\
\text { extent }\end{array}$ & $\begin{array}{c}\text { Moderate } \\
\text { extent }\end{array}$ & $\begin{array}{l}\text { Large } \\
\text { extent }\end{array}$ \\
\hline $\begin{array}{l}\text { HR practitioners are aware that some decisions } \\
\text { have ethical implications }\end{array}$ & 14,63 & 63,66 & 21,71 \\
\hline $\begin{array}{l}\text { Ethics is an everyday topic of conversation in } \\
\text { your company }\end{array}$ & 37,80 & 36,10 & 26,10 \\
\hline You have a need for formal training in ethics & 37,32 & 33,66 & 29,02 \\
\hline Ethics training is responsibility of the *IPM & 36,10 & 33,41 & 30,49 \\
\hline $\begin{array}{l}\text { You have a need for informal advice/coaching re } \\
\text { ethical issues }\end{array}$ & 31,22 & 37,80 & 30,98 \\
\hline You actually use the **SABPP Code of Ethics & 32,44 & 33,66 & 33,90 \\
\hline $\begin{array}{l}\text { The current SABPP Code of Ethics is an } \\
\text { adequate guideline for the behaviour of HR } \\
\text { practitioners }\end{array}$ & 11,46 & 54,15 & 34,39 \\
\hline $\begin{array}{l}\text { A company's ethics officer should be an ex-HR } \\
\text { practitioner }\end{array}$ & 20,00 & 39,51 & 40,49 \\
\hline Ethics training is the responsibility of SABPP & 24,39 & 33,17 & 42,44 \\
\hline $\begin{array}{l}\text { You have competence to manage ethics in your } \\
\text { organisation }\end{array}$ & 8,29 & 41,46 & 50,24 \\
\hline There is an ethical climate in your company & 12,93 & 36,59 & 50,49 \\
\hline $\begin{array}{l}\text { You feel equipped to facilitate a problem-solving } \\
\text { session with an ethical issue as theme }\end{array}$ & 9,27 & 36,83 & 53,90 \\
\hline $\begin{array}{l}\text { HR should assume responsibility for managing } \\
\text { ethics in organisation }\end{array}$ & 13,66 & 31,95 & 54,39 \\
\hline $\begin{array}{l}\text { Managing ethics should be a Key Performance } \\
\text { Area for HR practitioners }\end{array}$ & 9,76 & 32,44 & 57,80 \\
\hline You feel competent to deal with ethical issues & 2,93 & 37,56 & 59,51 \\
\hline Ethics training is responsibility of the company & 10,49 & 28,78 & 60,73 \\
\hline Ethics training is responsibility of universities & 5,37 & 31,95 & 62,68 \\
\hline $\begin{array}{l}\text { You recognise possible ethical implications in a } \\
\text { decision-making situation }\end{array}$ & 1,71 & 34,15 & 64,15 \\
\hline $\begin{array}{l}\text { Managing ethics should be a key competence } \\
\text { of HR practitioners }\end{array}$ & 3,66 & 29,27 & 67,07 \\
\hline $\begin{array}{l}\text { Business ethics should be included in the } \\
\text { training of HR practitioners }\end{array}$ & 1,95 & 13,90 & 84,15 \\
\hline HR should be involved in business ethics & 1,46 & 9,76 & 88,78 \\
\hline
\end{tabular}

$\mathrm{N}=410$

* IPM = Institute for People Management (South Africa)

** SABPP = South African Board for Personnel Practice

To reduce the dimensionality, these questions were factor analysed to determine the underlying constructs. Principal factor analysis was used and the number of factors extracted were based on the Kaiser criterion (number of eigenvalues $>1$ ) (Tabachnick \& Fidell, 2001). To assist in the interpretation, a Varimax (orthogonal rotation) was used (Tabachnick \& Fidell, 2001). Two reliable factors (Cronbach alpha values exceeding 0,7 (Hair, Anderson, Tatham \& Black, 1998)) each containing at least 4 items were extracted. These related to the extent to which HR practitioners have an ethics management competence and the extent to which HR has a role in managing ethics. The number of items per factor as well as the reliability coefficient of each appear in Table 2 .

TABLE 2

FACTORS RELATED TO THE ROLE OF HR IN DEALING WITH ETHICAL ISSUES

\begin{tabular}{lccl}
\hline Factor & $\begin{array}{c}\text { Reliability } \\
\text { (Coefficient } \\
\text { Alpha) }\end{array}$ & $\begin{array}{c}\text { Number } \\
\text { of items }\end{array}$ & Sample item \\
\hline $\begin{array}{l}\text { Extent to which HR } \\
\text { practitioners have an } \\
\text { ethics management } \\
\text { competence }\end{array}$ & 0,707 & 8 & $\begin{array}{l}\text { To what extent do you } \\
\text { feel competent to deal } \\
\text { with ethical issues? }\end{array}$ \\
$\begin{array}{l}\text { Extent to which ethics } \\
\text { is the responsibility } \\
\text { of HR }\end{array}$ & 0,769 & 4 & $\begin{array}{l}\text { To what extent should } \\
\text { HR be involved in } \\
\text { business ethics? }\end{array}$ \\
\hline
\end{tabular}


Descriptive statistics for each of the reliable factors are shown in Table 3 and are graphically displayed in Figure 2. The negative skewness of the distributions and the high mean values show that the majority of respondents indicated that HR practitioners have an ethics competence $(\mathrm{M}=2,54)$ and also that ethics is a responsibility of $\mathrm{HR}$ $(\mathrm{M}=2,43)$.

TABLE 3

DESCRIPTIVE STATISTICS OF FACTORS RELATING TO THE ROLE OF HR IN DEALING WITH ETHICAL ISSUES

\begin{tabular}{lcccc}
\hline Factor & Minimum & Maximum & Mean & SD \\
\hline $\begin{array}{l}\text { Extent to which HR practitioners } \\
\text { have an ethics management } \\
\text { competence }\end{array}$ & 1,50 & 3,00 & 2,54 & 0,324 \\
$\begin{array}{l}\text { Extent to which ethics is the } \\
\text { responsibility of HR }\end{array}$ & 1,00 & 3,00 & 2,43 & 0,520 \\
\hline
\end{tabular}

$\mathrm{N}=410$
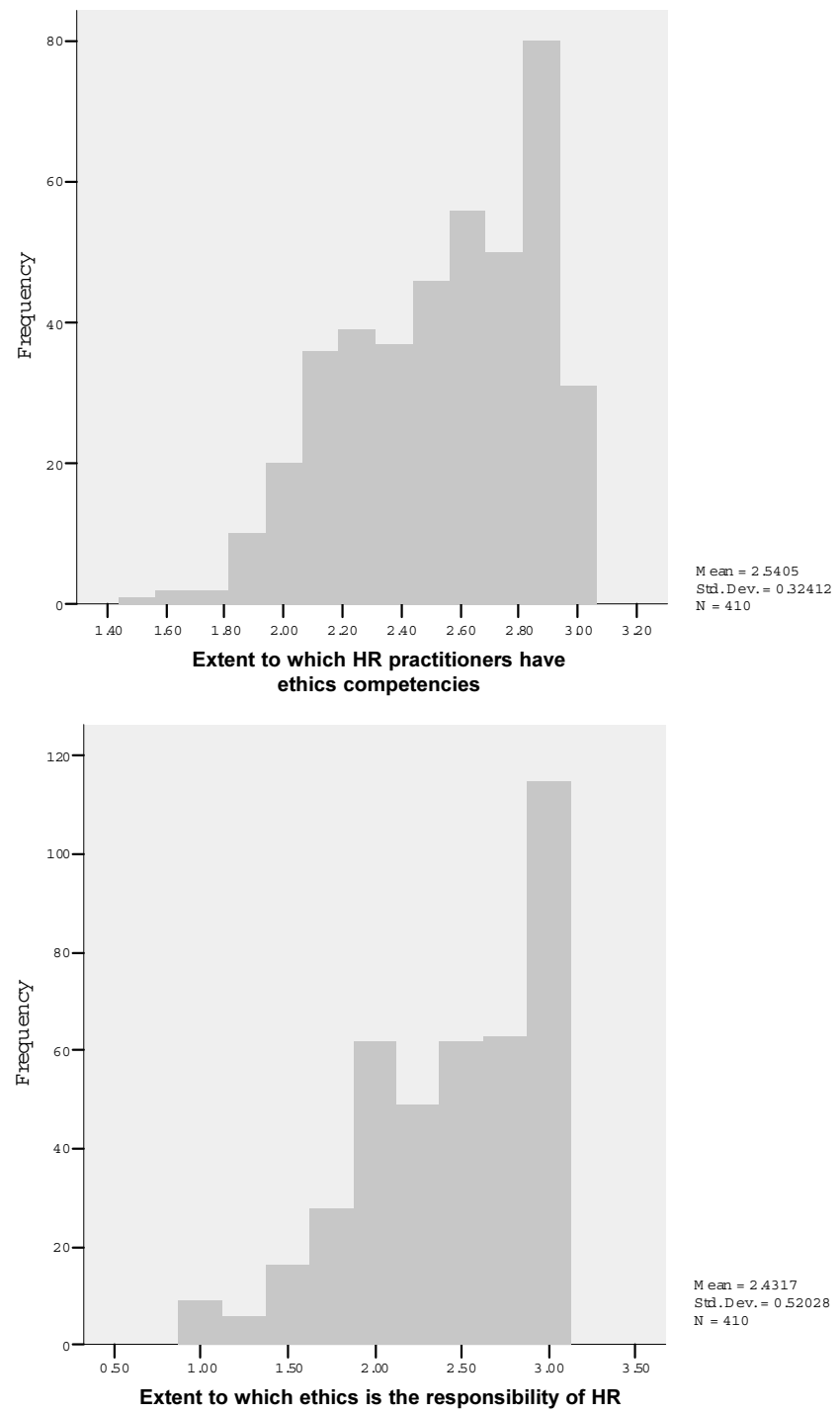

Figure 2: Distribution of factors relating to the role of HR in dealing with ethical issues

\section{Description of items related to exposure to ethics} management in an organisation

Of the 363 respondents $(88,5 \%$ of the 410 respondents $)$ who answered all of the yes/no questions related to exposure to ethics management within an organisation, the percen- tage of 'yes' responses to each question is displayed in Table 4 . Of interest is that only $47,93 \%$ of the 363 respondents reported that their organisations have codes of ethics and only $57,3 \%$ reported being familiar with the King Report on Corporate Governance. In contrast, $83,2 \%$ reported that cases of fraud or corruption occurred within their organisations.

TABLE 4

Percentage of yes Responses (SORTED In INCREasing ORDER OF MAGNITUDE) TO EXPOSURE TO ETHICS MANAGEMENT QUESTIONS

\begin{tabular}{lc}
\hline Question & $\begin{array}{c}\% \text { of yes } \\
\text { responses }\end{array}$ \\
\hline Does your company have an ethics office? & 9,64 \\
Does your company have an ethics committee? & 14,05 \\
$\begin{array}{l}\text { Does your company include managing ethics as a generic key } \\
\text { performance area of line managers? }\end{array}$ & 19,56 \\
$\begin{array}{l}\text { Does your company have a hotline to answer ethics queries? } \\
\text { Does your company provide training in business ethics? }\end{array}$ & 24,24 \\
$\begin{array}{l}\text { Does your company report on business ethics in its annual } \\
\text { report? }\end{array}$ & 27,00 \\
$\begin{array}{l}\text { Does your company have a formal ethics strategy? } \\
\text { Does your company have a code of ethics? }\end{array}$ & 47,93 \\
Does your company make provision for whistle-blowing? & 47,93 \\
$\begin{array}{l}\text { Are you familiar with the recommendations of the King } \\
\text { Report on Corporate Governance? }\end{array}$ & 53,72 \\
$\begin{array}{l}\text { Is ethical behaviour a core value in your company's values } \\
\text { statement? }\end{array}$ & 68,87 \\
Have there been cases of fraud/corruption in your organisation? & 83,20 \\
\hline N = 363 & \\
\hline
\end{tabular}

To quantify the extent of exposure to ethics management within an organisation further, the number of 'yes' responses to these 12 questions was determined for each respondent. Respondents were subsequently categorised into three groups based on the extent of exposure to ethics management: no to little exposure ( 0 to 3 yes answers), moderate exposure ( 4 to 6 yes answers) and a great deal of exposure ( 7 to 12 yes answers). This categorisation yielded the following percentage of respondents in each group: $37,5 \%, 35 \%$ and $27,5 \%$.

Towards finding a moderator for belief regarding ethics being a responsibility of HR and the ethics competencies of HR practitioners

To determine which, if any, of the background variables moderate the perception of respondents about 1) the extent to which HR practitioners have an ethics competence and 2) the extent to which ethics should be a responsibility of HR, ANOVAs and t-tests were performed. In each case, the null-hypothesis of equal population means was tested.

As far as background variables are concerned, none of the variables age group of practitioners, experience in the HR field and gender were found to moderate these perceptions ( $p$-values $>0,05$ in both cases). The same held true for their actual levels of formal education.

In terms of belief regarding the extent to which formal education provided adequate training in ethics, the null-hypotheses of equal population means were rejected for 1) the extent to which HR practitioners have an ethics management competence, as well as 2) the extent to which ethics should be a responsibility of HR (p-values < 0.05). The results of the ANOVAs are shown in Table 5 . 
TABLE 5

ANOVA RESULTS OF FACTORS IN TERMS OF EXTENT TO WHICH FORMAL EDUCATION PROVIDED ADEQUATE TRAINING IN ETHICS

\begin{tabular}{|c|c|c|c|c|c|c|}
\hline Factor & & $\begin{array}{l}\text { SS (Sum } \\
\text { of squares) }\end{array}$ & $\mathrm{df}$ & Mean SS & F & $\mathrm{p}$-value \\
\hline \multirow{4}{*}{$\begin{array}{l}\text { Extent to which HR } \\
\text { practitioners have } \\
\text { an ethics management } \\
\text { competence }\end{array}$} & $\begin{array}{l}\text { Between } \\
\text { Groups }\end{array}$ & 3,275 & 5 & 0,655 & \multirow[t]{4}{*}{6,666} & \multirow[t]{4}{*}{$<0,0005$} \\
\hline & Within & 39,692 & 404 & 0,098 & & \\
\hline & Groups & & & & & \\
\hline & Total & 42,967 & 409 & & & \\
\hline
\end{tabular}

$\begin{array}{llccccc}\begin{array}{l}\text { Extent to which ethics } \\ \text { is responsibility of HR }\end{array} & \begin{array}{l}\text { Between } \\ \text { Groups }\end{array} & 3,124 & 5 & 0,625 & 2,346 & 0,041 \\ & \begin{array}{l}\text { Within } \\ \text { Groups } \\ \text { Total }\end{array} & 107,589 & 404 & 0,266 & \\ & 110,713 & 409 & & \end{array}$

To elucidate the differences between these groups, post-hoc comparisons were performed. As equal population variances could not be assumed for the first factor (extent to which HR practitioners have an ethics competence), the Dunnett T3 comparison was used. The assumption of equal population variances could, however, be assumed for the second factor (extent to which ethics is the responsibility of HR) and hence the Scheffe post-hoc comparisons were used. The post-hoc comparisons revealed that practitioners who indicated that their formal education provided them with totally adequate training in ethics, on average believed that HR practitioners have more ethics management competence $(M=2,79)$ than those who indicated that their formal education provided them with marginally adequate to totally inadequate training $(\mathrm{M}=2,45$ and 2,43 respectively). Similarly those who believed that their formal education provided them with totally adequate training in ethics believed to a larger extent that HR should be responsible for ethics $(\mathrm{M}=2,73)$ than those who believed their training was inadequate $(\mathrm{M}=2,31)$. The effect sizes of 0,265 and 0,149 indicate that the effect of perception regarding the adequacy of ethics training during formal education has a small effect (Rosenthal, Rosnow \& Rubin, 2000:4) on the extent to which practitioners believe that they have an ethics management competence on the one hand, and the extent to which they believe HR should be responsible for ethics on the other.

As far as exposure to ethics management in an organisation is concerned, the null-hypotheses of equal population means were also rejected in both cases. The results of the ANOVAs are shown in Table 6.

TABLE 6

ANOVA RESULTS OF FACTORS IN TERMS OF EXTENT EXPOSURE TO ETHICS MANAGEMENT IN AN ORGANISATION

\begin{tabular}{|c|c|c|c|c|c|}
\hline Factor & $\begin{array}{l}\text { SS (Sum } \\
\text { of squares) }\end{array}$ & df & Mean SS & F & p-value \\
\hline $\begin{array}{l}\text { Extent to which HR practitioners } \\
\text { have an ethics management } \\
\text { competence }\end{array}$ & $\begin{array}{c}1,41 \\
37,46 \\
38,88\end{array}$ & $\begin{array}{c}2 \\
360 \\
362\end{array}$ & $\begin{array}{l}0,707 \\
0,104\end{array}$ & 6,79 & 0,001 \\
\hline $\begin{array}{l}\text { Extent to which ethics is the } \\
\text { responsibility of HR }\end{array}$ & $\begin{array}{c}1,95 \\
96,34 \\
98,29\end{array}$ & $\begin{array}{c}2 \\
360 \\
362\end{array}$ & $\begin{array}{l}0,975 \\
0,268\end{array}$ & 3,65 & 0,027 \\
\hline
\end{tabular}

The Scheffe post-hoc comparisons (used due to the assumption of equal population variances being assumed in both cases) revealed that practitioners with no to little exposure to ethics management have a significantly lower mean $(M=2,47)$ than those with a great deal of exposure $(M=2,63)$ in terms of the extent to which HR practitioners have an ethics competence. However, as far as the extent to which ethics is the responsibility of HR is concerned, those with no or little exposure to ethics management have a higher mean $(\mathrm{M}=2,52)$, and therefore believe to a greater extent that ethics management is HR's responsibility, than either those with a moderate $(\mathrm{M}=2,36)$ or a great deal of exposure $(\mathrm{M}=2,38)$

Hence it is concluded that both belief regarding the adequacy of ethics training during formal education and exposure to ethics management, seem to moderate belief regarding the ethics management competence of practitioners and the extent to which HR should be involved in ethics.

\section{DISCUSSION}

The results of this survey have shown that, although HR practitioners agree that they have an ethics management competence and that HR should be involved in ethics within an organisation, it is their belief about the adequacy of their formal training that moderates this and not their actual level of formal training. It can be surmised that HR's perceived competence to deal with ethics may be a reflection of the phenomenon that the majority of issues covered by corporate codes of ethics relate to some extent to employees' contracts with the company, HR issues in other words.

The results also showed that exposure to ethics management within an organisation, i.e. a context where ethics is taken seriously and addressed formally, moderates belief regarding both the ethics management competence of practitioners and the extent to which HR should be involved in ethics. Of interest is the fact that practitioners with a great deal of exposure believe to a larger extent that they have an ethics management competence, but believe to a lesser extent that HR should be involved in ethics management. This may be attributed to the fact that exposure to ethics management has highlighted their operational competencies in dealing with ethics on the one hand, but may reflect their realization of the practical limitations of possibly assuming a primary responsibility for managing organisational ethics. This may, in turn, be ascribed to either their lack of positional power within organisational hierarchies or the lack of credibility that still taints the HR function and its incumbents in many South African organisations. HR practitioners may therefore perceive themselves as unable to "enforce ethical business behaviour" (a requirement suggested by Caudron, 1997, p. 63).

Practitioners may also be hesitant to commit themselves to a substantive involvement in organisational ethics and assume a primary responsibility for ethics management for some of the reasons mentioned earlier: e.g. ethics being just another soft, 'welfarist' issue to be presented for buy-in from line, doubts over HR's ability to actually influence organisational ethics, line management absolving themselves of their responsibility for ethics since it "is now HR's problem", the possibility that taking care of ethics may dilute the newly established business partner role, and the phenomenon that a responsibility for ethics should not be added as an additional burden to an already saturated HR role).

Ethical behaviour is about human behaviour. Since HR practitioners need to be experts on human behaviour, it stands to reason then that $\mathrm{HR}$ must, in some way, be able to understand and have a substantial influence on organisational ethical behaviour. It is for this reason that professional HR associations and their members (HR practitioners) should embrace their ethics management responsibility. The nature and extent of this responsibility should, however, be elucidated and specific ethics management roles within this broader responsibility should be identified and clearly demarcated. In particular, HR tertiary education and professional training need to include business ethics knowledge and an ethics management competence. 


\section{REFERENCES}

Alreck, P.L. \& Settle, R.B. (1995). The survey research handbook (2nd ed.). Chicago: Irwin.

Arkin, A. (1996). Open business is good for business. People Management, 11 January, 24-27.

Armstrong, M. (1995). A handbook of personnel management \& practice. London: Kogan Page.

Bartels, L.K., Harrick, E., Martell, K. \& Strickland, D. (1998). The relationship between ethical climate and ethical problems within Human Resource Management. Journal of Business Ethics, 17, 799-804.

Berenbeim, R.E. (1991). HR taking a policy role in corporate ethics programs. Employment Relations Today, 279-285.

Brewster, C., Carey, L., Dowling, P., Grobler, P., Holland, P. \& Wärnich, S. (2003). Contemporary issues in human resource management: gaining a competitive advantage ( $2^{\text {nd }}$ ed.). Cape Town: Oxford University Press.

Caudron, S. (1997). World-class executives. Industry Week, 246 (22), 60-66.

Compton, K. (1997). Resolve for the new year. HR Magazine, 42 (1), 151 .

Connock, S. \& Johns, T. (1995). Ethical leadership. London: Institute of Personnel and Development.

Danley, J., Harrick, E., Schaefer, D., Strickland, D. \& Sullivan, G. (1996). HR's view of ethics in the work place: are the Barbarians at the Gate? Journal of Business Ethics, 15, 273-285.

Digh, P. (1997). Shades of gray in the global marketplace. HR Magazine, 42 (4), 90-98.

Driscoll, D.M. \& Hoffman, W.M. (1998). HR plays a central role in ethics programs. Workforce, 77 (4), 121-123.

Drummond, J. \& Bain, B. (Eds.) (1994). Managing business ethics: 9-25. Oxford: Butterworth Heinemann.

EOA (Ethics Officer Association). (1999). www.eoa.org. General information.

EOA (2002). www.eoa.org.

Flynn, G, (1995). Make employee ethics your business. Personnel Journal, 74 (6), 30-40.

Foote, D. \& Robinson, I. (1999). The role of the human resources manager: strategist or conscience of the organisation? Business Ethics: A European Review, 8 (2), 88-98.

Foote, D. (2001). The question of ethical hypocrisy in human resource management in the U.K. and Irish charity sectors. Journal of Business Ethics, 34, 25-38.

Greengard, S. (1997). 50\% of your employees are lying, cheating and stealing. Workforce, 76 (10), 44-53.

Grensing-Pophal, L. (1998). Walking the tightrope, balancing risks \& gains. HR Magazine, 43 (11),112-119.

Hair, J.F. Jr., Anderson, R.E., Tatham, R.L. \& Black, W.C. (1998). Multivariate data analysis. $5^{\text {th }}$ edition. New Jersey: Prentice Hall.
Hosmer, L.T. (1987). Ethical analysis and human resource management. Human Resource Management, 26 (3), 313-330.

IoD. (2002). Second King report on corporate governance for South Africa. Johannesburg: Institute of directors (IoD).

Johns, T. (1995). Don't be afraid of the moral maze. People Management, 5 October, 32-34.

Kays, D.J. (1988). Values underlying personnel/human resource management: Implications of the bishops' economic pastoral letter. Journal of Business Ethics, 7, 459-466.

Kilcourse, T. (1994). A human resource philosophy. Management Decision, 32 (9), 37-42.

Lawler, E.E. (1988). Human resources management: meeting the new challenges. Personnel, 22-27.

Losey, M.R. (1997). The future HR professional: competency buttressed by advocacy and ethics. Human Resource Management, 36 (1), 147-150.

Pickard, J. (1995). Prepare to make a moral judgement. People Management, 4 May, 22-25.

Pocock, P. (1989). Is business ethics a contradiction in terms? Personnel Management, November, 60-63.

Raelin, J.A. (1987). The professional as the executives ethical aide-de-camp. The Academy of Management Executive, 1 (3), 171-182.

Robertson, D.C. \& Schlegelmilch, B.B. (1993). Corporate institutionalisation of ethics in the United States and Great Britian. Journal of Business Ethics, 12, 301-312.

Rosenthal, R., Rosnow, R.L. \& Rubin, D.B. (2000). Contrasts and Effect Sizes in Behavioural Research: a Correlational Approach. Cambridge: Cambridge University Press.

Rossouw, D. \& Van Vuuren, L.J. (2004). Business ethics (3rd ed.) Cape Town: Oxford University Press.

Sadler, T. (1995). HRM: Developing a strategic approach. London: Kogan Page.

Smith, H.R. \& Carroll, A.B. (1984). Organisational ethics: A stacked deck. Journal of Business Ethics, 3, 95-100.

Tabachnick, B.G. \& Fidell, L.S. (1998). Using multivariate statistics, $4^{\text {th }}$ edition. Needham Heights, Massachusetts: Allyn and Bacon.

Torrington, D. \& Hall, L. (1995). Personnel management: HRM in action. Hemel Hempstead: Prentice Hall.

Ulrich, D. (1997). Judge me more by my future than by my past. Human Resource Management, 36 (1), 5-8.

Wehrmeyer, W. (1996). Green policies can help to bear fruit. People Management, 22 February, 38-40.

Wiley, C. (1998). Re-examining perceived ethics issues and ethics roles among employment managers. Journal of Business Ethics, 17, 147-161.

Winstanley, D. \& Woodall, J. \& Heery, E. (1996). Business ethics and human resource management: themes and issues. Personnel Review, 25 (6), 5-12. 